\title{
The Nordic Welfare Model in the Wake of Post-WWII Transformations and Algorithms of Changing Social Policy
}

\author{
By Guy Bäckman*
}

\begin{abstract}
The paper examines the adaption of the Nordic welfare model to changing circumstances after WW-II. The Nordic welfare model, providing generous welfare and security, is distinct from the other types of welfare state; the Liberal, Conservative-corporatist (Esping-Andersen 1990), and the later added Mediterranean welfare type and Postsocialist type (Ferrera 1996, Deacon 1993). After the expansive post-WWII period, the economic slowdown in the 1970s accompanied by problems connected with inequalities and increasing commitments in social policy, to a great extent because of population ageing, began to put pressure on the Nordic welfare states. The progress in technoscience and changed values in the new welfare culture, derived from the cultural turn and paradigm shift in social sciences and also influenced by the economic and social transformations, paved the way for rapid digital transformation and big data analytics. These changes provided possibilities to take another look at experiences of changed economic and social developments to face the new trends, risks, and needs to provide welfare and security by means of new social arrangements, such as for example redesign of the eldercare. New ways of thinking about values, have allowed the planning and implementation of social arrangements in the direction of plurality, also including privatization and informalization. Diversity is challenging universalism. The new digital and algorithmic culture, with new opportunities for utilization of the vast amount of information has been of great help in planning and decision-making, for example, in social investments. The economic recovery, together with good governance, guides transformative social policy by use of artificial intelligence in algorithmic solutions and robotism.
\end{abstract}

Keywords: Algorithms, Artificial intelligence, Digital and algorithmic culture, Good governance, Social expenditures, Transformative social policy.

\section{Introduction}

The foundations of the Nordic welfare states were laid during the first decades of the "Golden Age", 1945-1973, a period of economic expansion and prosperity. Sweden became the leading Nordic welfare state and a strong representative of the Nordic model, also applicable for the other Nordic countries, Denmark, Finland, Iceland and Norway. The strong economic growth in Sweden after WWII until the middle of the 1970s increased the economic frames for a broad scope of public social policy, based on the old social democracy ideals of "People's Home", stressing that in a good home there is equality, consideration, cooperation, and helpfulness (Gould 2001: 28). According to the Nordic welfare model or the

*Professor Emeritus, Åbo Akademi University, Finland. 
social-democratic welfare model, social policy emphasizes solidarity expressed in universal coverage and equal treatment of all citizens. Through generous transfers to individuals and families, and publicly provided services financed by high taxes, the Nordic welfare systems became different from the other welfare state systems like those in the US and the conservative-corporatist systems, in for example Germany and France. The expansion of the public sector, especially the public social service and welfare sectors, has in comparison with other welfare systems, been strong in the Nordic countries (OECD 2017: 3).

The global crises and stagnant economic growth since the 1970s, accompanied by problems of increased inequalities and poverty, have, in connection with national structural changes, even begun to cause pressure on the Nordic welfare states (Stephens 1996: 55, Pierson 2001a: 410). The long tradition of Nordic welfare research, from the first Swedish Level of Living Survey (1968) and the research on the level of need satisfaction, to the following studies on changing social equality in the Nordic countries, has broadened the view of welfare, and also paved the way for new thinking about values in social policy (Kvist et al. 2012: 2-3). Attention has particularly been paid to the command over resources such as health, education, housing, security of life, culture and to political resources for fulfilment of one's own potential, based on early British thinking (Titmuss 1974: 29) and also drawn from John Rawls on social justice and Amartya Sen on capability and functioning, and ethics (Sen 1993: 30). The Finnish sociologist Erik Allardt shifted the focus from the resource approach to the level of need satisfaction, including relationships and social ties to family and kin, people in the neighborhood and institutions (Kvist et al. 2012: 2). The Nordic welfare research tradition is connected to the ideas of trust and social capital and their connections with good governance or quality of government, which is important for guidelines in social policy (Rothstein 2013: 19, Kvist et al. 2012: 2-3, Putnam 1993: 167).

The demographic changes and the increasing social expenditure have made it necessary to take another look at policy actions. The high quality of population statistics in the Nordic countries and the available projections have always been the most important basis for planning and decision making. In the post-WWII period, the digital age or information age also began to shift and further modernize the society into an economy based on communication technology, automation and computation. The advancing digital transformation, also opens up new opportunities for strategic planning in today's and future social policy. Under internal and external pressures, the Nordic countries have been finding it necessary to review their past experiences and face new trends, risks, and needs in order to make changes in decision-making in social policies. This work, earlier obtained by human beings from changed economic and social developments, and findings from especially welfare research, has been taken over by automation and computation. In the new digital and algorithmic culture, a crowd of facts and ideas are sorted and classified into intelligible estimates that govern actors in the way they look at new policies when the circumstances have changed dramatically (Gere 2008, Striphas 2015, Beer 2017). The governments have also become aware of the importance of technological innovation especially in the ICT sector for 
improvement of production and service capacity (Gylfason et al. 2010: 30, Holmström et al. 2014: 6-7, OECD 2017a). The advanced technology and algorithmic solutions began to give the governments new and powerful possibilities to monitor fiscal and other trends and to develop strategies for a sustainable development in line with social policy goals. The scarcity of economic resources has restrained social investments to ensure a healthy and productive labor force in the future. The new digital and algorithmic culture, together with the economic growth, which is estimated to improve in the coming years, has given the Nordic welfare model new opportunities to manage all commitments in social policy and to plan for social investments.

The broad framework is the well-known typology of welfare states, proposed by Esping-Andersen (1990) and the Mediterranean and Post-socialist welfare regimes (Ferrera 1996, Arts and Gelissen 2002: 142, 149-150, Deacon and Standing 1993), which all include an ideological and cultural base. In the examination of the Nordic welfare model and its social policy, which pertains to Denmark, Finland, Iceland, Norway and Sweden, we follow an analyticcomparative social policy approach, which implies studies of different political, cultural, social, and systemic factors insofar as they impact on human well-being in functional and dysfunctional ways (see Mohan 2018: 29-31). The main question remains, will the Nordic welfare states in the era of transformations and innovative digital culture be able to change their social policies and still continue to provide their populations with high levels of welfare and security measures.

\section{Transformations Generate Fiscal Stress}

The post-WWII period of economic growth and prosperity came to an end after the oil crisis of 1973, triggered by the Arab-Israeli War and the Iranian Revolution. The economic slowdown and the increasing commitments and social spending in social policy, have put pressure on the Nordic welfare systems. The economic slowdown, poverty, income and health inequalities, and lack of opportunities for education and employment are dividing our societies and undermining our economies and democracies (OECD 2008, Piketty 2014: 23, 25, Atkinson 2015: 63-64, 81, Stiglitz 2013: 151-153, Stiglitz 2015: 88, 178). Unpredictable risks such as wars, catastrophes and terrorism are plaguing the world today. The increasing streams of refugees are also giving rise to social and economic concerns. In the early 1980s, the new global situation was perceived as a major economic crisis and policy efforts were launched to curb rising expenditure. The increasing social expenditure, population changes, especially the everincreasing older population, and the requirement for good health and professional skills of the labor force and unemployment, were observed as pressure not only on the governments and the authorities, but also on the productive population.

\section{Expanding Commitments in Social Policy - Increasing Social Expenditure}

After the end of the "Golden Age", the social expenditure began to increase 
causing pressure on the Nordic welfare state, and this increased strongly during the recession and its aftermath during the first years of the 1990s (Figure 1). Thereafter, a decrease in expenditure and a rather unchanged trend can be seen until 2008-2009 when a distinct peak is again visible, caused by the financial crisis. This crisis, also known as the global financial crisis, is considered to have been the worst financial crisis since the Great Depression of the 1930s. Since the crisis, social expenditure has slightly decreased and is now, except in Norway and Iceland, about $30 \%$ of GDP. The average for the EU-28 countries is $28.7 \%$ (Eurostat 2017).

Figure 1. Total Public Social Expenditures as a Percentage of GDP in the Nordic Countries, 1990-2015

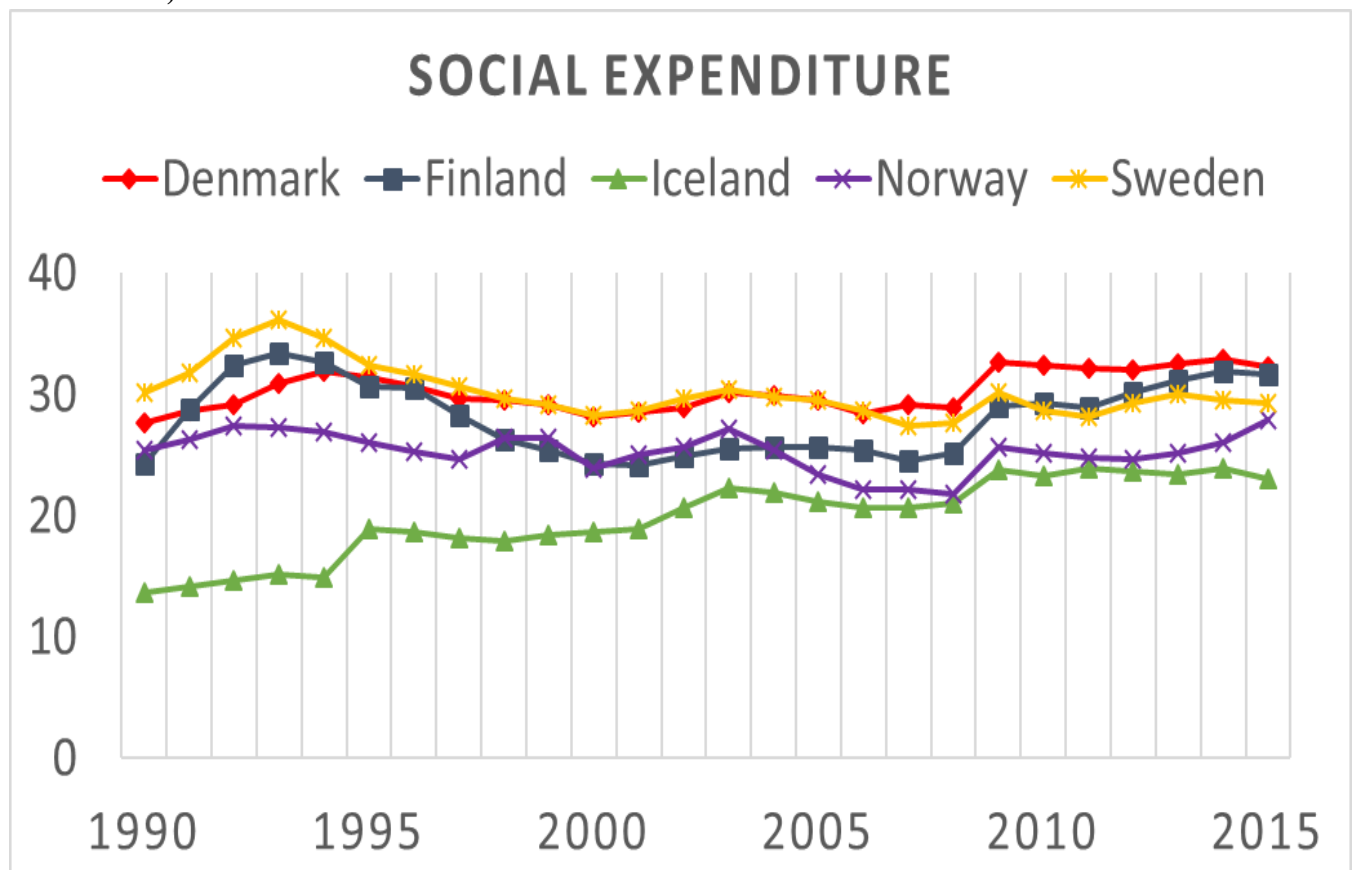

Source: Eurostat 2017; OSF 2017 (Appendix Tables 7, 8).

The policy has been that the demands are increasing but financing becomes problematic (Andersen 2004, Andersen et al. 2007: 83). Sweden showed an example by changing existing social policy programs, e.g. expansion of waiting days for unemployment and sickness benefits, a freeze on adjustments in child allowances, and a rise in the retirement age. The changing circumstances and the high tax burden also made it necessary for the other Nordic countries to adjust welfare programs according to established goals and to adapt to changing demands, values and norms (Stephens 1996: 43, 55, Pierson 2001a: 425).

In the Nordic countries the public expenditure on old age is a substantial component (mainly early retirement and old age pensions, institutional care and housing services, home care and support for informal care), varying in 2015 between 35\% (Norway) and 42\% (Sweden), although lower in Iceland (26\%), of the total social expenditure. The combined expenditure for old age and sickness is more than $50 \%$ of the total social expenditure, in Sweden in fact two-thirds 
(Nososco 2016: 252). The length of time that people remain active in the labour market, greatly affects social spending on sickness and disability. Besides demographic changes, with major implications for social policy, certain other characteristics of the population such as, for example health and unemployment, and welfare state developments contribute to the maintenance of benefits and services at the already achieved level. The activities of trade unions and federations of employers in labor market policies, as well as in other social policies, women's labor force participation, and also voters as recipients of benefits and services and as employed in the welfare sector, are connected to the post-industrial transformations implying an increase of employment in the welfare sector, support to maintain commitments in social policy at the achieved level, and with increasing social spending as a power-resource approach (Pierson 2001a: 412, 440, Korpi 2003: 590). The share of social spending for families and children of the total social spending has not changed appreciably since 2000, and is now about $11-12 \%$ of the total social spending (Nososcco 2016: 252). The challenges for future family policies, and also for the power resources of actors in social policy, are linked to social investments in education and protection for promoting inclusion and ensuring the labor force (Morel et al. 2016: 2, 8, 11, Hemerijick 2016: 47-49).

\section{Demographic Changes}

Great demographic transformations have taken place in the Nordic countries. The general pattern is that the proportion of the elderly is increasing, the proportion of children is decreasing, as is the working population. By 2050, the proportion of the population aged 65 and over in the Nordic countries is predicted to be between 20\% and 25\% of the total populations (Nordic Statistics 2017: 34). The demographic shifts have an impact on the possibilities to maintain sufficient high employment for economic growth and to act for development and progress in social policy. The Nordic countries have, with the exception of Finland, succeeded in maintaining higher and quite stable employment (Holmström et al. 2014: 6, Nordic Statistics 2017: 26). In February 2018, Finland had an employment rate of about $70 \%$ among persons aged 15-64 years, which is still lower than in the other Nordic countries (OSF 2018). The goal of the Finnish government is to reach $72 \%$ in the coming years. The reason for the lower employment rate in Finland is connected with early retirement. Since the 1950s, Finnish men, especially middleaged men have been found to be in poor health, affecting their functional ability in working life (Bäckman and Dallmer 2000: 25). The decreasing trend in male employment begins about six years earlier in Finland, at the age of 54, than in the other Nordic countries (Nososco 2016: 33). The demographic changes have greatly affected the dependency ratios, calculated as the share of the population aged 65 years and over in relation to the population of working age 15-64 years. The dependency ratios will continue to increase remarkably in the Nordic counties until 2030. Although changes in the eldercare in favor of care at home have taken place and the new technology can support the care of the elderly even in their own homes, the increase in the populations aged 85 years and over implies that there 
should also be advanced and regularly supervised institutional and hospital care according to the estimated need. For those older people not in need of professional care, but in need of social or minor health care, long-term home care can be given by informal caregivers like spouses, children or other family members, supported financially by the government (Riedel and Kraus 2011: 28, Szebehely and Meagher 2013: 274). An effective and well-functioning eldercare also requires an increased partnership between home, service institutions and hospital for the organization and utilization of different forms of care.

The demographic shifts are of crucial importance in the planning of social protection and productive social policy now and in the digital future, emphasizing more strongly than earlier efforts towards a social investment welfare state, where especially the children and the population of working age are focused on (Hemerijck 2016: 49). Other investments, such as impact investing, can potentially provide new ways to allocate private capital to address challenges facing the mixed system of provision of services, and thus generate both a social and an environmental impact (social return) alongside a financial return (O'Donohoe et al. 2010: 14). Social arrangements, capabilities and social opportunities are also important from the perspective of life satisfaction and happiness in a wellfunctioning society (Layard 2005: 111-113, Sen 2010: 269). The actors in social policy and decision-makers nowadays can exploit the knowledge that has been generated by the pervasion of digital technology, and the rapid progress in technoscience, and especially in information and communication technology (ICT).

\section{Algorithms of Transformative Social Policy}

Economic slowdown, risks and uncertainties are obstacles to the ability of social policy to realize goals to promote social arrangements through policy actions based on preferred values and goals in the welfare culture (van Oorschot et al. 2008, Mohan 2015: 125, Mohan 2018: 94, Bäckman 2016). There is, therefore, a need for transformative policy actions toward a new development, aiming at economic stability, justice and ecological sustainability, as well as increased trust in the ability of the governments and the political actors to handle the affairs. Social investments in children and young people as transformative social policy to ensure the health and working ability of the population of productive age, have to be planned to fit demographic and economic changes (Kangas and Rostgaard 2007, Meagher and Szebehely 2012: 89, Kuisma and Nygård 2015).

Growing dissatisfaction, social hope and visions of a new development, and new thinking about values and goals of social policy in a welfare culture call for policy actions on a broad front based on relevant information that can increasingly be produced by advanced technology. Changes can be carried out according to the formula ( $\mathrm{D} \times \mathrm{V} \times \mathrm{F}>\mathrm{R}$ ), where the dissatisfaction with the current situation (D) and the vision of what is possible $(\mathrm{V})$, and the first steps towards reaching this vision $(\mathrm{F})$ are greater than the resistance (R) to change. Dissatisfaction (D) describes, at a general level, how people sense that their capability to lead a good 
life is restricted and that their economic and social needs cannot be met. The governments cannot, because of fiscal stress, maintain the levels of commitments or provide more economic support. Low earnings, poor health, living at risk of poverty, are obstacles to a favorable outcome. Violence, terror, streams of refugees, environmental hazards are also giving rise to concerns for the governments. Policies in a visionary perspective (V) aspire to maintain economic stability and high employment, which make it possible to reduce inequality, to make social investments, and to strengthen the resources of power ("the citizen must have a voice"). Kowalsky (2015: xviii-xix), has referred to this as engendering hope and optimism as a way toward a new social development, through a comprehensive reform agenda.

\section{Algorithms of Change}

As a result economic crises, demographic changes and new thinking on values, capacity building or social investment, not only for social protection but also for a productive social policy, beginning with protection in early age to ensure the health and working ability of the population, have become new directions in social policy (Morel et al. 2016: 2-6, Hemerijck 2016: 46, 49). The focus is on development of opportunities for children to participate in early childhood care and education, and the efficient use of human capital through other supportive welfare arrangements, i.e. through day care, supporting women's and lone parents' employment. The new thinking about capacity building through social protection and productive social policy has its roots in the Swedish social-democratic ideas of social policy, particularly advocated by Alva and Gunnar Myrdal in the promotion of family policy in the 1930s.

The path-breaking discussions and change in social policy favouring social investments appear some years before and around the Millennium in the social policy agendas of the European Commission, the OECD and in the book "Why We Need a New Welfare State", addressing the need for a new look at the welfare state and its social investments (Esping-Andersen 2002). Morel et al. in their "Towards A Social Investment Welfare State" (4 ${ }^{\text {th }}$ ed. 2016), on the basis of findings from a project about the future of social investment from 1999, examine the social investment perspective as a new welfare paradigm; policies for development and progress aim at "preparing" rather than "repairing" (Morel et al. 2016: 1- 2, 11-12, Hemerijck 2016: 46-47). The ideas of the "new era of perspectives on social investment", with a life course perspective, leading on Rawlsian intergenerational justice, represents a new view of welfare provision, also in a long-term social policy for promoting social arrangements through policies based on existing values and goals in the welfare culture (van Oorschot et al. 2008, Bäckman 2016). Other investments, such as impact investing in supportive functions (OECD 2015, O'Donohoe at al. 2010: 14), e.g. day-care to promote the well-being and employment of parents with children, especially single parents, are of great significance for employment, growth and welfare (Sen 1999: 46-47, Esping-Andersen and Sarasa 2002: 5, 17-18, Bäckman 2015: 39). The impact investing can potentially provide new ways to allocate private capital, and 
thus generate both social and environmental impact (social return) alongside a financial return (O'Donohoe at al. 2010: 14).

Economic stability, solidarity, social justice, ecological sustainability and trust in governments are important goals for development and progress (Stiglitz 2013: 151-153, Grönlund and Setälä 2012). As a part of long-term environment policy, forest management is important for the quality of life and health of populations. Nordic studies show that forests with old, high trees, offering natural space, peace etc., contribute to human health and well-being as environments for recreation and rehabilitation (Nordström et al. 2015). The economic and social transformations have increased the importance of the welfare state and its new paradigm for social investments. The social policy agendas of the European Union, discussed, for example, in the reports from the European Council 2010 and the European Commission 2017, emphasizing growth, improvement of productivity and reducing risk of poverty and social exclusion but also environmental development, have influenced economic and social policy strategies in the Nordic countries (Kuitto 2016). The revolutionizing technology and communication, together with government intervention (good governance), has opened up new opportunities to get intelligible findings, based on an infinite number of important changes in politics and culture, facts about economic and social development for transformative social and welfare policy in a wide sense also for environmental protection and promotion of ecological sustainability (Mohan 2015: 33-34, 40, Stiglitz 2014: 16-19, Striphas 2015, Beer 2017).

\section{Artificial Intelligence and Effectiveness in Social Policy}

The availability of extensive information is connected to questions about the effectiveness in social policy, i.e. "how to get the right things done" with the population's trust in public institutions ("the voice of the citizens"), and also to the question of how to ensure a sufficient supply of skilled labor force in the ICT sector (van Oorschot et al. 2008: 5, 11, Atkinson 2015: 121-122). The international organizations (e.g. United Nations, European Commission) have, through their recommendations, in many ways encouraged member states to pave the way for an effective use of the revolutionizing technological possibilities (see e.g. European Commission 2013a, Eurostat 2017a). Good governance or quality of government, free from corruption and related phenomena, is a prerequisite for effective policy-making, for the achievement of goals and progress in social policy (Rothstein 2013: 22-26, Cath et al. 2018). William Baumol in his research from the 1960s paid attention to the imbalanced growth between the manufacturing and service sector in times of technological and employment change. The rising costs associated with labor-intensive service industries like the welfare sector (e.g. child care, eldercare, health), where the relative costs of services rise over time causing fiscal stress, has come to be called the "cost disease" or "Baumol's disease" (Baumol 2012: xvii, 19-20). Many welfare activities require human contacts and the values attached to public welfare services become important, encouraging social investments in human capital (Pierson 2001: 84, Atkinson 2015: 121-122). Well-planned investments in human capital and a well-educated labor force, 
facilitate adjustment to changing circumstances by making it easier to upgrade skills through additional life-long training (Gylfason et al. 2010: 30, 215). In the age of the current digital revolution, one of the important roles of governments is to encourage both research and development and upgrading of additional skills through training in the use of the new advanced technology (Atkinson 2015: 118123). Information technology and digitalization are sources of progress. Digitalization, automation and robotics, nowadays affect nearly all working tasks, and offers opportunities to raise labor productivity. A well-educated labor force can more easily adapt to changing circumstances and upgrade its skill through additional training when needed. Encouragement for research and development and investments in basic research to promote the generation of new knowledge and to improve opportunities to utilize this knowledge should be given high priority (Gylfason et al. 2010: 254, Holmström et al. 2014: 7, 10, 29-30).

Generally, there are multiple choices for prediction models widely used by statisticians and data scientists. Algorithms can be grouped according to type of method or purpose, for example, algorithms developed to solve scientific, e.g., biological, physical, and social, engineering, and humanities' problems (Breiman 2001). Already fifty years ago Lofti Zadeh introduced the concept of the fuzzy algorithm, which though fuzzy rather than precise, was considered to be of use in a wide variety of problems relating to information processing, control, artificial intelligence and, more generally, decision processes involving incomplete or uncertain data (Zadeh 1968). A wide range of applications exists, for example, to predict poverty, according to the machine or supervised learning method (Plulikova 2016: 8). The Gale-Shapley algorithm, named after the researchers, captures some "basic mechanisms in the dating market" (see Mackinnon 2016: 164-165). This method has shown to be important in the study of "how to match different agents as well as possible". For example, students have to be matched with schools, and donors of human organs with patients in need of a transplant. Lloyd Shapley received the 2012 Nobel Prize in Economics together with Alvin E. Roth. Graph coloring algorithms have been used in the visualization of findings from network analyses, for example to show how information about health problems and care of them can be spread in a chain consisting of many friends (Christakis and Fowler 2009: 116, 139, Bäckman 2013: 78-80).

Researchers have long searched for Artificial General Intelligence (AGI). By means of advanced and revolutionizing technology it has been possible to construct thinking and speaking robots. Sophia, the baby with advanced thoughts from 2016 and Erica, the Japanese android who was declared the most realistic female human robot of 2016, are examples of such robots. Sophia, modeled after actress Audrey Hepburn, has like Erica a human-like appearance and behavior. Both are capable of speech and holding a conversation with humans, thanks to a combination of speech-generation algorithms, facial-recognition technology and infrared sensors that allow them to track faces across a room. They would be suitable for service functions in healthcare, customer service, therapy and education (Goertzel 2016, Nevett 2017, Hanson Robotics 2018).

According to a survey carried out for the European Commission (2013) concerning ICT education in schools, high levels of virtual learning provision exist 
in the Nordic countries (2013: 33, 48). The study of and practice in computerbased training, online learning, and in the use of mobile technologies, vary, however, in different European countries. Sweden, for example, in 2011 launched the Digital Agenda, "ICT for Everyone - A Digital Agenda for Sweden", as proposed guiding principles and goals for the ICT policy. It involves every area of social and economic life, such as, for example, internet usage, human capital, public e-services, development and progress, in order to benefit from the development opportunities of ICT (GOS 2011: 13). In January 2018 the European Commission launched new measures to boost key competences and digital skills for better use of digital technology in teaching and learning, improving education through better data analysis and foresight, and developing the digital competences and skills needed for living and working in an age of digital transformation (European Commission 2018).

\section{The Digital Culture and Social Policy: The Nordic Countries a Family of their Own}

The digital culture, including all the opportunities of the advanced technology that the progress in technoscience has given rise to, is also a black box society, an open system without any knowledge of its working (see Pasquale 2015). The use of a great variety of information and different methods, has made it possible to use digital and intelligible solutions for human-social development. The Nordic societies have also been forced to build systems for misuse of data and cybercrime. After all, the revolutionizing technology and communication, together with government intervention (good governance), has opened up new opportunities to obtain intelligible findings, based on important changes in politics and culture, facts about economic and social development for transformative social and welfare policy and, in a wide sense, also for environmental protection and promotion of ecological sustainability (Mohan 2015: 33-34, 40, Stiglitz 2014: 16-19, Striphas 2015, Beer 2017). The Nordic countries have succeeded in continuously improving their digital performance (Figure 2), providing their citizens with efficient public services. The Nordic model has shown to be resilient and its social policy has, through use of advanced technology, succeeded in maintaining a high level of welfare and security, measured with indicators such as well-being, child mortality, high level of social capital, happiness and life satisfaction (Charron 2013: 59, Bäckman 2015: 82). It has been found to be difficult to prevent poverty among immigrants, especially in Sweden, where the number of immigrants has hugely increased. The Swedish authorities have, therefore, applied special solutions, for example, to give information via a smart phone application, "mobilearn", about available services. Preventing poverty among immigrants and young single adults and single parents is also a challenge for the Nordic welfare model (Kvist et al 2012a: 202, European Commission 2016).

The revolutionizing technology and communication, together with good governance, support transformative social policy in a wide sense also for environmental protection and promotion of ecological sustainability (Mohan 2015: 
33-34, 40, Stiglitz 2014: 16-19, Striphas 2015, Beer 2017). Recommendations, based on, for example, the European foresight project, Digital Futures, which is a journey into 2050 visions and policy challenges, and on welfare research strongly advocate such policy lines (European Commission 2013a; Gylfason et al. 2010, Stiglitz 2014; 2017). Due to the development of information and communications technology (ICT) and the expansion of education in this field, there is an increase in the number of employed ICT specialists as a percentage of total employment in the EU countries (Eurostat 2017a). Measured by the Digital Economy and Society Index (DESI) 2017 (European Commission 2017), which sums up relevant indicators on Europe's digital performance, the Nordic countries have the most advanced digital economies in the European Union (Figure 2). The UK is ranked $7^{\text {th }}$ and Germany $11^{\text {th }}$. Romania has the lowest scores on the DESI, e.g. level of human capital (basic and advanced skills), digital technology (business digitization and e-commerce), digital public services (services provided by the government), and broadband connections and use of the internet (citizen's use of content, communication and online transactions). The Nordic countries are also progressive in the further developing of their public services in the digital era.

Figure 2. Digital Economy and Society Index (DESI) $2017($ EU-28 = 100)

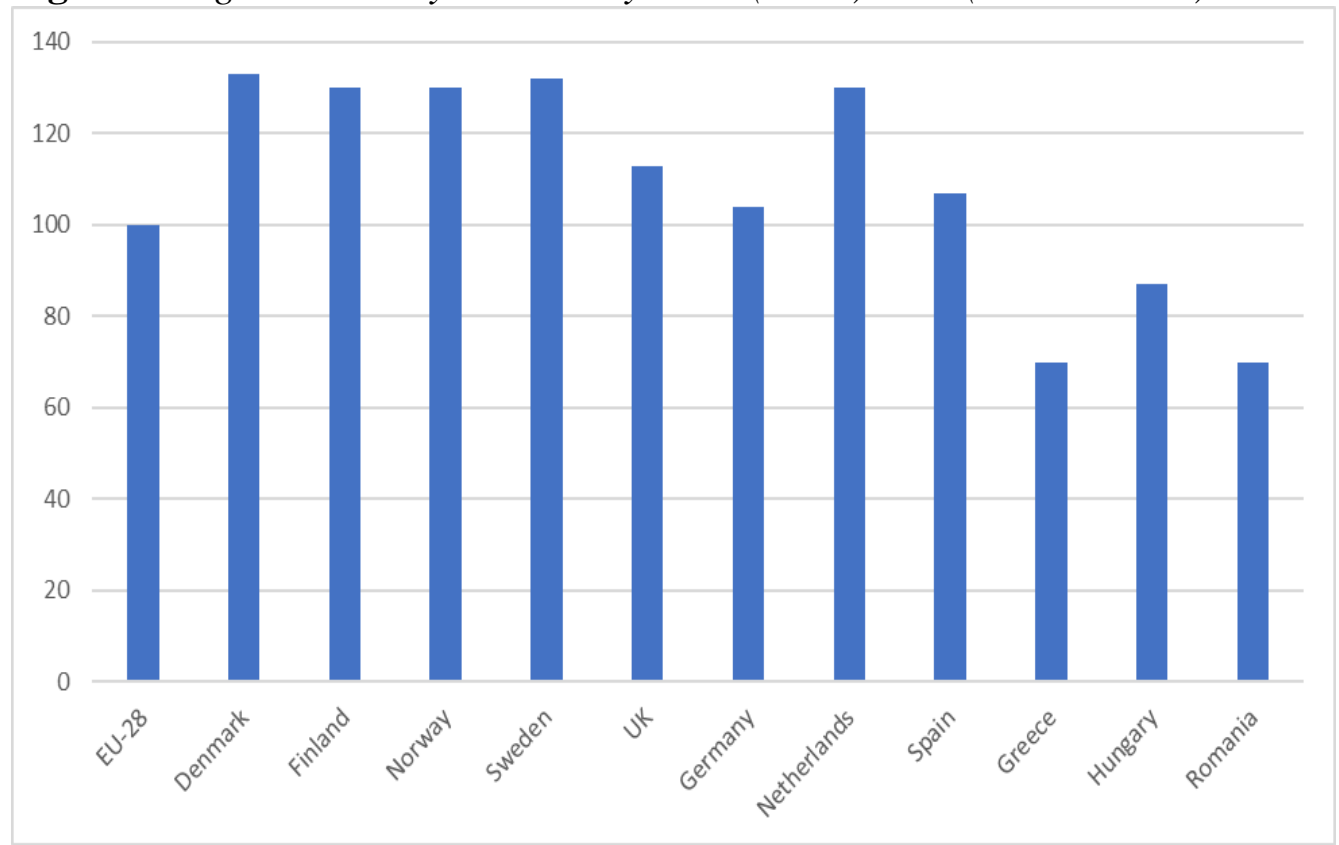

Source: European Commission 2017.

Individuals using the Internet to interact with public authorities (eGovernment Users) is higher in the Nordic countries than, for example, in the UK and Germany. This is to some extent associated with the income distribution, which is more equal in the Nordic countries and gives the households and individuals better opportunities to purchase modern technical equipment for use of the internet and communication than in many other countries. The economic circumstances among immigrants are challenging the Nordic welfare model (Fritzell et al. 2012: 176).

Data and algorithms are crucial in the government's shift towards data-driven 
policy-making in the digital and algorithmic culture. There is, however, also a pressing need to question the impact algorithms may have on both individual and societal values, such as autonomy, identity, equality and democracy. Algorithms govern not only policy-making and decision-making for the achievement of social policy goals, that promote welfare, social security and social satisfaction through social arrangements, but also the dark side of data-driven decision-making for social good such as, for example, violations of privacy (Pasquale 2015: 21, 184). The new welfare culture, emphasizing new values, and norms for goals and decision-making in social policy, has further encouraged us to derive advantages from technological advances. Research and development expenditure in the Nordic countries is internationally at a high level, especially Sweden, where the R \& D expenditure was $3.25 \%$ of GDP in 2016, has reached top international level (Eurostat 2017b). It is important to maintain a high level of education and research to ensure investment in human capital and a well-educated labor force for sustainable development based on new technological solutions as, for example, artificial intelligence. In the goal-setting for policy actions it is important to provide choices and to maintain service effectiveness, i.e. "to get the right things done". An estimation of needs and services, and the ethical and social justice values embedded in goal- and priority-settings are important, as are also the evaluation of implemented decisions. Good governance supports transformative social policy in a wide sense also for environmental protection and promotion of ecological sustainability (Mohan 2015: 33-34, 40, Stiglitz 2014: 16-19, Striphas 2015, Beer 2017). The Nordic countries have succeeded in continuously improving their public service sector in the new digital era, providing their citizens with efficient public services.

\section{Conclusion and Further Thoughts}

Many episodes and events, such as stagnation in the global economy and national economic and social development trends, have put pressure on the Nordic welfare model. Under internal and external pressures, the Nordic countries have been finding it necessary to review their past experiences and face new trends, risks, and needs in order to make changes in social policies. The advanced technology began to give the governments new and powerful possibilities to develop strategies for a sustainable development in line with social policy goals. The Nordic countries have succeeded in continuously improving their digital performance (Figure 2), providing their citizens with efficient public services. Although the digital technologies have been praised for progress in human-social development, the appearance of dark sides in the digital culture has caused new concerns. Implementing effective cybersecurity measures is challenging. The Nordic model has, however, shown to be resilient and its social policy has, through use of advanced technology, succeeded in maintaining a high level of welfare and security. The Nordic welfare states have also, in the era of great transformations, chosen new directions towards diversity and plurality emphasizing individual needs and private responsibility. 
Plurality has been implemented especially in the care of the elderly. A redesign of the eldercare has taken place in favor of care at home or in a home-like environment. Informalization and privatization have increased and constitute a form of social partnership, which involves institutionalized cooperation of key interest, freeing the governments from organizing different social arrangements. The Nordic welfare states have, also internationally, succeeded to implement diversified programs and also to maintain a high level of universal social policy, which increases the confidence in service providing. The progress in the advanced technology has enabled a wide range of opportunities for a sustainable social policy according to the core values of the Nordic welfare model.

The global economy is recovering and forecasts estimate that the global GDP growth will increase around $3.5-3.7 \%$ in 2018. In comparison with the fastest growing economies, India and China, the Nordic countries belong to the group of the slower growing economies; forecasts show a growth of about $2 \%$, but probably not over 3\% for the coming years. Weakness in potential growth is, however, visible (World Bank 2017: 4-5, Kose 2018: 2). The economic growth boosts investments, improves employment and productivity, all of which are necessary for progress. The Nordic countries as small open economies benefit from global growth, clearing the way for their governments to manage the commitments in social policy provided they can keep up with the digital developments. Unprecedented shifts in the global economy are, however, possible because of political tensions and wars, catastrophes etc. in different parts of the world, as well as changes within the countries such as population ageing, are factors which impact on the national economies and can also cause unprecedented budgetary stress.

The government is the primary institution through which people, politicians, administrators and planners collectively act to solve problems and make decisions about social policy goals. Good governance or the quality of government free from corruption and thereto related phenomena, has been found to be high in the Nordic countries. The Quality of Government correlates very strongly with a country's degree of economic development and is in many ways connected with good outcomes related to human well-being, a central goal of social policy, for example, low income inequality, low child mortality, high level of social capital, happiness and life satisfaction.

Progress in advanced digital technology and communication, and the advance of artificial intelligence (AI) will continue to affect every aspect of our lives as citizens and consumers. The above-mentioned thinking and speaking Sophia robot is a good example of the direction in which technological innovation and artificial intelligence (AI) is going. It is important that the governments ensure that goalsetting for performance improvement is of value even in the future. Social investments in children and young people as transformative social policy to ensure the health and working ability of the population of productive age, have to be planned to fit demographic and economic changes. The availability of a skilled labor force is important for a well-functioning economy in times of changing technology. Sustainable development and progress require a continuous capacity to build social protection and a productive social policy to ensure a skilled labor 
force to maintain the productivity made possible by technological change in the future.

A crucial problem in the goal-setting for policy actions is how to provide choices and to maintain service effectiveness, i.e. "to get the right things done". An estimation of needs and services, and the ethical and social justice values embedded in goal- and priority-settings are important, as are also the evaluation of implemented decisions. The use of advanced technology and communication and the rise of artificial intelligence will lead to dramatic changes in the future. The collective debate on critical public issues will draw on wider evidence because scientific observations and insights will be open to analysis by all. As a result, governments will be able to shape policies more dynamically and in a more participative way. People will have a voice in policy and decisions regarding public assets, projects, laws and regulations. Policy options could be tested beforehand in the virtual space before collaborative decisions are reached and implemented. The question is, whether there are enough ethical rules to guide the rapid development and increased use of advanced technology and communication to prevent the formation of "dark side" problems.

The utilization of advanced technology in policies oriented towards further development must above all be given high priority in social policies because today's decisions will have long-term consequences.

\section{References}

Andersen TM (2004) Challenges to the Scandinavian Welfare Model. European Journal of Political Economy 20(July): 743-754.

Andersen TM, Holmström B, Honkapohja S, Korkman S, Söderström HT, Vartiainen J (2007) The Nordic Model - Embracing Globalization and Sharing Risks. The Research Institute of the Finnish Economy (ETLA). Helsinki.

Arts W, Gelissen J (2002) Three Worlds of Welfare Capitalism or More? A Stateof-the-Art Report. Journal of European Social Policy 12(2): 137-158.

Atkinson AB (2015) Inequality. What Can Be Done? Cambridge, MA: Harvard University Press.

Baumol W, with contributions by de Ferranti D, Malach M, Pablos-Mendez A, Tabish H, Gomory Wu L (2012) The Cost disease: why computers get cheaper and health care doesn't. New Haven, CT: Yale University Press.

Beer D (2017) The Social Power of Algorithms. Information, Communication \& Society 2(1): 1-13.

Breiman L (2001) Statistical Modeling: The Two Cultures. Statistical Science 16(3): 199231.

Bäckman G (2016) The Welfare culture and the Redesign of Social Eldercare in Finland. Environment and Social Psychology 1(2): 118-129.

Bäckman G (2015) The European Welfare States, Social Policy and Social Justice. In J Laurinkari, F Unger (eds), The European Utopia in a Globalising Era, 30-52. European Academy of Science, Kuopio.

Bäckman G (2013) New Strategies for Promoting Health; with Special Regard to the Threats to Men's Health and Survival in Okinawa: In J Laurinkari, M Tarvainen (eds), The Systems of Inclusion - Perspectives to Disability and the Construction of Inclusion. Studies in Comparative Social Pedagogies and International Social Work 
and Social Policy, vol. XXV, 66-88. Europäischen Hochschulverlag GmbH \& Co. KG: Bremen.

Bäckman G, Dallmer J (2000) Pekka Kuusi's Plan”Sozialpolitik für die 60er” und der Beginn der Modernisierung der finnischen Sozialpolitik. Meddelanden från Ekonomisk-Statsvetenskapliga Fakulteten vid Åbo Akademi. Ser. A: 511. Åbo.

Cath C, Wachter S, Mittelstadt B, Mariarosaria T, Floridi L (2018) Artificial Intelligence and the 'Good Society': The US, EU, and UK approach. Sci. Eng. Ethics 24(2): 505528.

Charron N (2013) Evaluating EU Countries by QoG: National Level. In N Charron, V Lapuente, B Rothstein, (eds), Quality of Government and Corruption from a European Perspective. A Comparative Study of Good Government in EU Regions, 37-69. Cheltenham, UK: Edward Elgar.

Christakis NA, Fowler JH (2009) Connected. The Surprising Power of Our Social Networks and How They Shape Our Lives. New York: Little, Brown and Company.

Deacon B, Standing G (1993) Social Policy in Central and Eastern Europe. Journal of European Social Policy 3(3): 159-161. https://doi.org/10.1177/095892879300300 301.

Esping-Andersen G (1990) The Three Worlds of Capitalism. Princeton, NJ: Princeton University Press.

Esping-Andersen G (Ed) (2002) Why We Need a New Welfare State. New York: Oxford University Press.

European Commission (2018) New measures to boost key competences and digital skills. Retrieved from https://bit.ly/2mMMvpI.

European Commission (2017) The Digital Economy and Society Index (DESI). Retrieved from https://bit.ly/2bTPWVx.

European Commission (2016) Sweden Using a Digital App to Speed Up Migrant Integration. Retrieved from https://bit.ly/2SeRNIn.

European Commission (2013) Survey of Schools: ICT in Education. Retrieved from https://bit.ly/2PocEjv.

European Commission (2013a) Digital Futures. Final Report: a journey into 2050 visions and policy challenges. Retrieved from https://bit.ly/2CqNeVL.

Eurostat (2017) Social protection expenditure and receipt. Retrieved from https://bit.ly/ 2siUfAg.

Eurostat 2017a. Digital Economy and Society/Digital skills: ICT specialists in employment. Retrieved from https://bit.ly/2fcxBUN.

Eurostat (2017b). Research \& Development expenditure. Retrieved from https://bit.ly/2G sfRpw.

Ferrera M (1996) The "Southern"'” Model of Welfare in Social Europe. Journal of European Social Policy 6(1): 17-37.

Fritzell J, Bäckman O, Ritakallio V-M (2012) Income inequality and poverty: do the Nordic countries still constitute a family of their own? In J Kvist, J Fritzell, B Hvinden, O Kangas, (eds), Changing Social Equality. The Nordic welfare model in the 21st century, 165-185. Bristol, UK Polity Press.

Gere C (2008) Digital Culture. London: Reaktion Book.

Goertzel B (2016) The AGI Revolution: An Inside View of the Rise of Artificial General Intelligence. San Jose, CA: Humanity Press.

Gould A. (2001) Developments in Swedish Social Policy. London: Palgrave Macmillan.

Government Offices of Sweden (GOS) (2011) ICT for Everyone - A Digital Agenda for Sweden. Retrieved from https://bit.ly/2EDm6VT.

Grönlund K, Setälä M (2012) In Honest Officials We Trust: Institutional Confidence in Europe. American Review Of Public Administration Journal 42(5): 523-542. 
Gylfason T, Holmström B, Korkman S, Söderström HT, Vihriälä V (2010) Nordics in Global Crisis. Vulnerability and resilience. The Research Institute of the Finnish Economy (ETLA).

Hanson Robotics (2018) Sophia robot. Retrieved from https://bit.ly/2rKLMaH.

Hemerijck A (2016) Two or three waves of welfare state transformation? In N Morel, B Palier, J Palme, (eds), Towards a Social Investment Welfare State? Ideas, Policies and Challenges, 33-60. Bristol, UK: Polity Press.

Holmström B, Korkman S, Pohjola M (2014) The nature of Finland's economic crisis and the prerequisites for growth', memorandum. Prime minister's office. Helsinki.

Kangas O, Rostgaard T (2007) Preferences or care context? Predictors for working life opportunities in seven European countries. Journal of European Social Policy 17(3): 240-256.

Korpi W (2003) Welfare State Regress in Western Europe: Politics, Institutions, Globalization, and Europeanization. Swedish Institute for Social Research (SOFI). Stockholm University. Working Paper 5/2003.

Kose MA (2018) Global Economic Prospects: Broad-Based Upturn, but for How Long? The World Bank. Retrieved from https://bit.ly/2Bv3HGU.

Kowalsky R (2015) Foreword. In B Mohan, (auth and ed), Global Frontiers of Social Development in Theory and Practice. Climate, Economy, and Justice, xvii-xxii. New York: Palgrave Macmillan.

Kuisma M, Nygård M (2015) The European Union and the Nordic models of welfare-path dependency or policy harmonisation? In CH Grøn, P Nedergaard, A Wivel, (eds), The Nordic Countries and the European Union. Still the Other European Community? The Nordic Countries and the European Union, 158-172. London: Routledge.

Kuitto K (2016) From social security to social investment? Compensating and social investment welfare policies in a life course perspective. Journal of European Social Policy 26(5): 442-459.

Kvist J, Fritzell J, Hvinden B, Kangas O (2012) Changing social inequality and the Nordic welfare model. In J Kvist, J Fritzell, B Hvinden, O Kangas (eds), Changing Social Equality. The Nordic welfare model in the 21st century, 1-22. Bristol, UK: Polity Press.

Kvist J, Fritzell J, Hvinden B, Kangas O (2012a) Nordic responses to rising inequalities: still pursuing a distinct path or joining the rest? In J Kvist, J Fritzell, B Hvinden, O Kangas, (eds), Changing Social Equality. The Nordic welfare model in the 21st century, 201-206. Bristol, UK: Polity Press.

Layard R (2005) Happiness. Lessons from a New Science. Penguin Books, London.

Mackinnon L (2016) Love's Algorithm. In L Amoore, V Piotukh, Algorithmic Life. Calculative devices in the age of big data, 161-175. New York: Routledge.

Meagher G, Szebehely M (2012) Equality in the social service state: Nordic childcare models in comparative perspective. In J Kvist, J Fritzell, B Hvinden, O Kangas, (eds), Changing Social Equality. The Nordic welfare model in the 21st century, 89-118. Bristol, UK: Polity Press.

Mohan B (2018) The Future of Social Work. Seven pillars of practice. Thousand Oaks, CA: SAGE.

Mohan B (2015) Global Frontiers of Social Development in Theory and Practice. Climate, Economy, and Justice. New York: Palgrave Macmillan.

Morel N, Palier B, Palme J (2016) Beyond the welfare state as we knew it? In N Morel, B Palier, J Palme, (eds), Towards a Social Investment Welfare State? Ideas, Policies and Challenges, 1-30. Bristol, UK: Polity Press.

Nevett J (2017) Meet Erica, the most "beatiful" and "human-like" android with "soul" that will "change life" forever. Retrieved from https://bit.ly/2R6CcgE. 
Nordic Statistics (2017) Nordic Council of Ministers. Statistics Denmark.

Nordström E-M, Dolling A, Skärbäck E, Stoltz J, Grahn P, Lundell Y (2015) Forests for wood production and stress recovery: trade-offs in long-term management planning. European Journal of Forest Research 134(5): 755-767.

Nososco (2016) Social Protection in the Nordic Countries. Scope, Expenditure and Financing. Nordic Social Statistical Committee 63: 2017.

O'Donohoe N, Leijonhufvud C, Saltuk Y (2010) Impact Investments: An Emerging Asset Class. J. P. Morgan Global Research. Retrieved from https://bit.ly/2V6mVeW.

Organisation for Economic Co-operation and Development (OECD) (2017) Employment in General Government. Government at a Glance 2017. Paris: OECD Publishing.

Organisation for Economic Co-operation and Development (OECD) (2017a) OECD Science, Technology and Industry Scoreboard 2017. The Digital Transformation. Paris: OECD Publishing.

Organisation for Economic Co-operation and Development (OECD) (2015) Impact Investment. Building the Evidence Base. Paris: OECD Publishing.

Organisation for Economic Co-operation and Development (OECD) (2008). Growing Unequal? Income Distribution and Poverty in OECD Countries. Paris: OECD Publishing.

Official Statistics of Finland (OSF) (2018) Labour force survey 2018, February. Statistics Finland.

Official Statistics of Finland, (OSF) (2017) Social protection expenditure and financing 2015. The National Institute for Health and Welfare. Statistical Report 7/2017.

Pasquale F (2015) The Black Box Society: The Secret Algorithms that Control Money and Information. London: Harvard University Press.

Pierson P (2001) Post-Industrial Pressures on the Mature Welfare States. In P Pierson, (ed), The New Politics of the Welfare State, 80-104. New York: Oxford University Press.

Pierson P (2001a) Coping with Permanent Austerity. Welfare State Restructuring in Affluent Democracies. In P Pierson (ed), The New Politics of the Welfare State, 410456. New York: Oxford University Press.

Piketty T (2014) Capital in the Twenty-First Century. Cambridge. MA: Harvard University Press.

Plulikova N (2016) Poverty Analysis Using Machine Learning, Comenius University in Bratislava, Faculty of Mathematics, Physics and Informatics. Thesis. Retrieved from https://bit.ly/2ExLr2A.

Putnam RD (1993) Making Democracy Work: Civic Traditions in Modern Italy. Princeton, NJ: Princeton University Press.

Riedel M, Kraus M (2011) Informal Care Provision in Europe: Regulation and Profile Providers. ENEPRI Research Report No. 96.

Rothstein B (2013) Conceptualizing QoG. In N Charron, V Lapuente, B Rothstein (eds), Quality of Government and Corruption from a European Perspective. A Comparative Study of Good Government in EU Regions, 16-34. London: Edgar Elgar.

Sen A (2010) The Idea of Justice. New York: Penguin Books.

Sen A (1999) Development as Freedom. New York: Anchor Books.

Sen A (1993) Capability and Well-Being. In M Nussbaum, A Sen (eds), The Quality of Life, 30-53. New York: Oxford University Press.

Stephens JD (1996) The Scandinavian Welfare States: Achievements, Crisis, and Prospects. In G Esping-Andersen (ed), Welfare States in Transition. National Adaptations in Global Economies, 32-65. London: SAGE.

Stiglitz JE (2015) The Great Divide New York: W.W. Norton \& Comp.

Stiglitz JE (2014) Leaders and Followers: Perspectives on the Nordic Model and the 
Vol. 6, No. 3 Bäckman: The Nordic Welfare Model in the Wake of Post-WWII...

Economics of Innovation. NBER Working Paper Series. Working Paper 20493. Retrieved from https://bit.ly/1sXrodr.

Stiglitz JE (2013) The Price of Inequality. How Today's Divided Society Endangers Our Future. New York: W. W. Norton \& Company.

Striphas T (2015) Algorithmic culture. European Journal of Cultural Studies 18(4-5): 395-412.

Szebehely M, Meagher G (2013) Four Nordic countries - four responses to the international trend of marketisation. In G Meagher, M Szebehely (eds), Marketisation in Nordic eldercare: a research report on legislation, oversight, extent and consequences. Stockholm Studies in Social Work 30, 241-288. Stockholm University, Department of Social Work.

Titmuss RM (1974) Social Policy. London: Allen \& Unwin.

van Oorschot W, Opielka M, Pfau-Effinger B (2008) The culture of the welfare state: historical and theoretical arguments. In W van Oorschot, M Opielka, B Pfau-Effinger (eds), Culture and Welfare State. Values and Social Policy in Comparative Perspective, 1-26. Cheltenham, UK: Edward Elgar.

World Bank Group (2017) Global Economic Prospects, June 2017: A Fragile Recovery. Washington, DC: World Bank. Washington, DC: World Bank. doi:10.1596/978-14648-1024-4.

Zadeh LA (1968) Fuzzy algorithms. Information Control 12(2): 94-102. 